Commentary

\title{
Governance Lessons from Urban Informality
}

\author{
Hugo Sarmiento and Chris Tilly * \\ Department of Urban Planning, University of California, Los Angeles, CA 90095, USA; E-Mail: hugos@ucla.edu (H.S.), \\ tilly@ucla.edu (C.T.) \\ * Corresponding author
}

Submitted: 19 September 2017 | Accepted: 2 April 2018 | Published: 3 April 2018

\begin{abstract}
We locate this issue's papers on a spectrum of radicalism. We then examine that spectrum, and the governance mechanisms described, through the lens of a significant arena of urban counter-planning: the urban informal economy. Drawing on our own research on self-organization by informal workers and settlers, as well as broader literatures, we suggest useful lessons for reinventing urban governance.
\end{abstract}

\section{Keywords}

bottom-up; counter-planning; governance; informal economy; informality; radicalism; social movements; top-down; urban planning

\section{Issue}

This commentary is part of the issue "Co-Producing Urban Governance for Social Innovation", edited by Liz Richardson (University of Manchester, UK).

(C) 2018 by the authors; licensee Cogitatio (Lisbon, Portugal). This article is licensed under a Creative Commons Attribution 4.0 International License (CC BY).

\section{Introduction}

Starting from critiques of urban governance, the five articles in this issue formulate varied alternatives. In this commentary, we first locate the papers on a spectrum of radicalism. We then examine that spectrum, and the governance mechanisms described, through the lens of what is arguably the largest area of urban counterplanning, bottom-up planning, or co-production of governance: the urban informal economy. Drawing on our own research on self-organization by informal workers and settlers, as well as broader literatures, we suggest useful lessons for reinventing urban governance.

\section{The Radicalism Spectrum}

The five papers' alternative models of urban governance can be characterized by their degree of radicalism or rupture from technocratic, top-down state administration. Wagenaar and Wood (2018) radicalize the concept of public innovation by challenging the importation of corporate logic to the public sphere and by defining cit- izens as well as the state as potential innovators, but ultimately they introduce citizen innovation as a complement to state action. Perry, Patel, Bretzer and Polk (2018) go farther, spotlighting local interaction platforms that assemble varied stakeholders to co-produce knowledge and strategy for urban sustainability. Dean (2018) takes the ruptural step of categorizing citizen conflict, as well as collaboration, with the state, as a form of participation in governance. Silver's (2018) "everyday radicalism" moves beyond dissensus to rebellion and utopian prefiguration. Finally Atkinson, Dörfler and Rothfuß (2018) classify climate change-directed self-organization into four categories spanning the full spectrum from consensusbuilders comfortably engaged with the state to radical greens bent on utopia-building.

\section{Movements of Urban Informal Actors}

The broad variety of informal activities in U.S. and Latin American cities has been widely noted (Mukhija \& Loukaitou-Sideris, 2016; Portes, Castells, \& Benton, 1989). Much has also been written on how the neolib- 
eral restructuring projects of the last few decades, characterized by the state's retreat from regulating labor and housing markets contributed to the growth of informal sectors, spaces, and practices in which these actors operate. Our concern, however, is with understanding informal actors' contributions to governance: understanding how, in the current period of development, displacement and disinvestment, workers and settlers in these cities have often succeeded in winning recognition for their rights of access and possession despite breaching laws and regulations. For instance, Los Angeles construction day laborers, Mexico City street vendors and Bogota waste recyclers defend their right to ply their trades in urban spaces that are by law off limits to them (Rosaldo, 2016; Sarmiento, de la Garza, Gayosso, \& Tilly, 2016). In Latin America newcomers to the city extra-legally seize land to build informal settlements that later win state recognition. How do they accomplish these things? At times they simply take advantage of gaps in the enforcement capacity of the state, but we are interested in cases in which they confront, rather than evade, the power of the state, yet succeed nonetheless.

To begin, we point out the nature of the threat to these actors is tied to a shared feature across this wide and varied geography, their state-sanctioned exclusion from formal labor and housing markets. As they are often immigrants in American cities or rural-to-urban migrants in Latin American cities their exclusion is codified in part by immigration policies and other state policies which determine the legality of their presence in the city, in part by policies specifying the boundaries of legal market activity. The strategies, arguments, and actions these workers and settlers deploy to meet their economic and housing needs are thus also necessarily political because they are not, or not principally, waging claims against employers and landlords but in fact subverting state power and negotiating the legality of their very presence in the city. Generally, a principal goal for these actors, then, is to resist displacement, maintain autonomy in their territory, and gain the right to use land and urban space in socially and culturally specific ways.

We find a convergence around two increasingly common strategies. A first strategy involves demonstrating social-cultural attachment to their labor and housing practices and a territorial identity, which can become sources of symbolic power (Chun, 2009) in confrontations with the state or private property-owners. Crucial to this resistance has been self-organization, most often outside of formally recognized labor unions and political parties, not only to organize worksites and neighborhoods but to "jump scales" and organize in policy domains ancillary to the formal labor and housing markets (Evans \& Kay, 2008; Gastón, 2017). The aim here is an attempt to deflect existential threats such as deportation and displacement. These localized practices can be amplified through the construction of counter-publics (Fraser, 1990), networks of varied sympathetic actors.

Self-organization thus creates basic legitimacy and credibility (of the promise of votes or other support, or threat of protest). These organizations tend to be small, with modest economic clout, and much of their activity can be qualified as pre-figurative and aspirational, emphasizing the empowerment of their constituencies through programmatic interventions. However, in certain cases, urban informal workers and settlers have developed new tactics and discourses to interact with the public-at-large, and project political power via alliances with more powerful political actors. Figure 1 illustrates this process schematically.

Examples include the worker centers found in Lons Angeles and New York which have become cornerstones of the immigrant rights movements in the U.S., the street vendor associations in Mexico City organizing for indigenous rights, and the popular housing organizations in Bogota organizing for los desplazados, migrants displaced to the city by the decades long civil war. Mexican street vendors cite the pre-Hispanic indigenous origins of their practice, the tianguis open-air markets held for centuries in the population centers of Mesoamerica. On this basis, these street vendors appeal to the constitutional rights afforded to indigenous communities and the preservation of their cultural autonomy. Housing rights activists in Colombia similarly invoke constitutional rights afforded to desplazados in defense of their ability to build informal settlements in the periphery of cities like Bogota. In Los Angeles, construction day laborers have harnessed laws protecting free speech and the familiar meme of the enterprising immigrant in order to win the right to

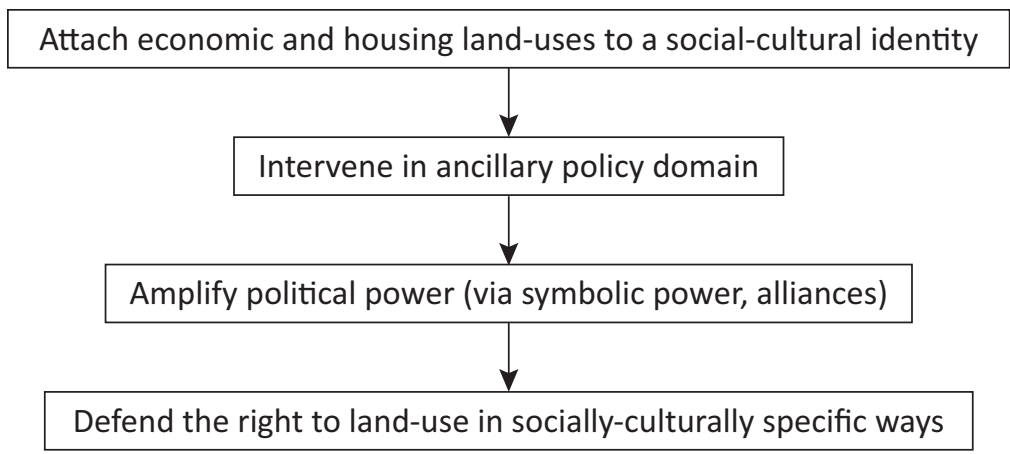

Figure 1. How excluded urban actors win rights. 
solicit work in public spaces and even private ones (such as the parking lots of home improvement stores). Los Angeles' street vendors recently followed suit, winning decriminalization of street vending in the city, meaning local police can no longer arrest street vendors and charge them with offenses which previously could lead to deportation.

A second, more emergent strategy informal workers and settlers adopt is the recognition, anticipation and appropriation of developmental discourses tied to environmental concerns. Today urban redevelopment projects in these cities, and more generally large-scale private investments in urban centers, are framed in terms of their social and environmental impacts. Developers and investors have become adept at formulating public relations strategies which stress their contribution to "smart" growth, and "sustainable" and "socially inclusive" development. And while these investments carry potentially dislocating effects, we find the workers and settlers we consider here are also learning to identify the threats and opportunities implied by these discursive strategies. For example, informal settlers in Bogota who have "invaded" peripheral lands categorized in land-use maps as protected forest reserves argue their housing practices, informed a particular social-cultural relationship to land, represents a more environmentally sensitive and balanced interaction with the natural environment. Their alternative is counter-posed to those proposed by developers often high-rise residential towers which ostensibly aim at reducing the city's housing deficit and land scarcity problem. In New York and Los Angeles day laborers and street vendors also make counter-arguments such as emphasizing how their economic activity better addresses the city's efforts to "activate" public spaces and leverage the economic potential of planning strategies such as transit-oriented development. These arguments, which combine social-cultural and technical discourses, are presented as alternatives to dominant paradigms of development and investment patterns.

Ultimately, both strategies, shifting across policy domains and coopting "sustainable development" discourses, can be understood as a reaction to the threat of dislocation and displacement, and therefore a relatively passive assertion over particular uses of urban space and territory. Their success is defined by their ability to limit or redirect the reach of state policies in particular spaces, and to persist their activities. In other words, these workers and settlers have as post-colonial theorist Asef Bayat (2000) puts it "quietly encroached" on urban territory and resorted to political lines of action from a defensive posture. However, to the extent they have been able to create counter-publics, establish and nurture alliances with more powerful political actors and institutions such as mainstream labor unions, political parties and locally elected officials, they are successfully intervening in policy domains. One such policy is immigration law which governs and regulates not only movement through urban territories but also participation in urban labor and housing markets. In this manner, they are successfully amplifying their power to shape and restructure existing forms of urban governance in these cities-with the potential to push the frontiers of that power even farther.

\section{Lessons for Governance}

Reflecting on the issue's discussions of governance in light of collective action by urban informal actors points to five lessons.

First, governance of markets is a central urban governance arena. Informal actors reorganize markets for labor, land and other resources. However, discussion of markets is sparse in this issue's articles, despite their context of market-centered capitalism.

Second, our informal actors are compelled to engage with the state, despite evasion of state regulation being definitional to informality, suggesting that even those seeking to opt out of state-led processes often must contend with the state. This lesson seems particularly relevant regarding Atkinson et al.'s (2018) three groups (out of four) of climate change activists that chose autonomy relative to the state.

Third, though a radicalism spectrum is conceptually useful, real world organizations often move across the spectrum, and combine strategies from across the spectrum. Histories of day laborer or waste picker action amply document this. We should not reify our radicalism quaternary any more than the top-down/bottom-up binary.

Fourth, utopia is a tall order, but self-organization according to a dissident logic can move people toward prefiguration. Despite the limited objectives of these organizations, at times they achieve collectivity that transcends traditional social relations-mirroring Atkinson et al.'s (2018) and Silver's (2018) groups rooted in pragmatism but nonetheless inspired to reach for utopia.

Finally, however, self-organization according to a dissident logic comes in many varieties. While some movements of urban informal actors prefigure radical utopias, there are also mafia-style Mexican street vendor associations replicating state command structures and corruption; informal settlements' parallel land markets can reproduce the inequalities and rent-seeking of formal markets. We should therefore avoid glorifying or otherwise essentializing "communities" or "citizens" and their forms or participation.

\section{Conclusion}

We typically discuss alternative urban governance models as ways to solve large, complex problems-budgeting, resilience and sustainability, infrastructure planningbut cases are usually small and often experimental. Informal urban workers and settlers are tackling local micro-problems-earning a livelihood, finding a homebut doing it at scale in cities across the globe. Urban scholars would do well to continue learning from these experiences. 


\section{Conflict of Interests}

The authors declare no conflict of interests.

\section{References}

Atkinson, R., Dörfler, T., \& Rothfuß, E. (2018). Selforganisation and the co-production of governance: The challenge of local responses to climate change. Politics and Governance, 6(1), 169-179.

Bayat, A. (2000). From 'dangerous classes' to 'quiet rebels': Politics of the urban subaltern in the Global South. International Sociology, 15(3), 533-557.

Chun, J. J. (2009). Organizing at the margins. Ithaca, NY: Cornell.

Dean, R. J. (2018). Counter-governance: Citizen participation beyond collaboration. Politics and Governance, 6(1), 180-188.

Evans, R., \& Kay, T. (2008). How environmentalists' greened' trade policy: Strategic action and the architecture of field overlap. American Sociological Review, 73(6), 970-991.

Fraser, N. (1990). Rethinking the public sphere. Durham, NC: Duke University Press.

Gastón, P. (2017). Contention across social fields: Manipulating the boundaries of labor struggle in the work- place, community, and market. Social Problems. doi: 10.1093/socpro/spw039

Mukhija, V., \& Loukaitou-Sideris, A. (2016). The informal American city. Cambridge, MA: MIT Press.

Perry, B., Patel, Z., Bretzer, Y. N., \& Polk, M. (2018). Organising for co-production: Local interaction platforms for urban sustainability. Politics and Governance, 6(1), 189-198.

Portes, A., Castells, M., \& Benton, L. (Eds.). (1989). The informal economy. Baltimore, MD: Johns Hopkins University Press.

Rosaldo, M. (2016). Revolution in the garbage dump: The political and economic foundations of the Colombian recycler movement. Social Problems, 63, 351-372.

Sarmiento, H., de la Garza, E., Gayosso, J. L., \& Tilly, C. (2016). The unexpected power of informal workers in the public square: A comparison of Mexican and US organizing models. International Labor and Working Class History, 89, 131-152.

Silver, D. (2018). Everyday radicalism and the democratic imagination: Dissensus, rebellion and utopia. Politics and Governance, 6(1), 161-168.

Wagenaar, H., \& Wood, M. (2018). The precarious politics of public innovation. Politics and Governance, 6(1), 150-160.

\section{About the Authors}

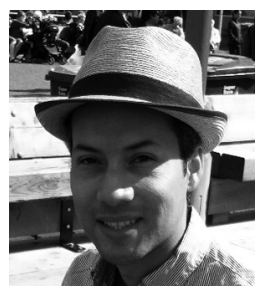

Hugo Sarmiento is a doctoral candidate in urban planning interested in applying a critical perspective to the study of housing and economic development especially as it relates to environmental policy such as climate change and risk management. His work is guided by a political and economic frame, and the central notion people and their cultural practices are the basis for building more socially and environmentally just cities. Hugo has a special interest in Latin American urban geographies having completed projects in Guatemala, El Salvador, Colombia and Brazil. Currently, his dissertation work examines social mobilization and grassroots resistance to housing resettlement programs in Colombian cities concerned with adapting to the effects of climate change.

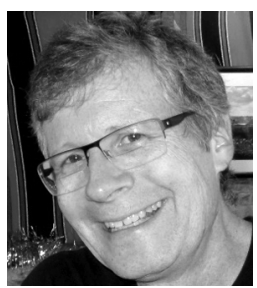

Chris Tilly, Professor of Urban Planning at UCLA, studies labor and inequality in the U.S. and global context, with a particular focus on bad jobs and how to make them better. Tilly's books include Half a Job: Bad and Good Part-Time Jobs in a Changing Labor Market; Glass Ceilings and Bottomless Pits: Women's Work, Women's Poverty; Work Under Capitalism: Stories Employers Tell: Race, Skill, and Hiring in America; The Gloves-Off Economy: Labor Standards at the Bottom of America's Labor Market; Are Bad Jobs Inevitable?; and Where Bad Jobs Are Better: Retail Jobs across Countries and Companies. 